\title{
Seasonal changes of the biochemical composition of marine particulate matter with special reference to fatty acids and sterols
}

\author{
P. Mayzaud, J. P. Chanut*, R. G. Ackman** \\ INRS-Océanologie, 310 Allée Des Ursulines, Rimouski, Québec, Canada G5L 3A1
}

\begin{abstract}
Seasonal changes in particulate size spectra, biochemical composition, fatty acid and sterol content were followed from winter to fall in a small north Atlantic coastal basin. Strong seasonality, related to both spring-bloom and summer biological production, was recorded for most chemical and biochemical descriptors. Size spectra were generally characterized by dominance of small particles in the size range $6.35-25.4 \mu \mathrm{m}$ equivalent diameter, except in early summer when an additional component in the $32.0-64.0 \mu \mathrm{m}$ size range became important. Changes in either C: $N$ ratio or carbohydrate:protein ratio indicated physiological changes which could be related to nutrient limitation or senescence. The fatty acid and sterol composition of the lipid fraction displayed major seasonal changes which reflected: (1) the seasonal heterogeneity of the taxonomic composition of the particles; (2) the physiological changes within each group of organism; and (3) the various periods of low production or bloom decay. Spring bloom production of small to medium size particles $(12.7-50.8 \mu \mathrm{m})$ was associated with C16 polyunsaturated acid, 20:5w3, 24 methylene-cholesterol and desmosterol. Summer production of small particles $(2.0-6.4 \mu \mathrm{m})$ was associated with C18 polyunsaturated acids, 22:6 603 , nor-24-cholesterol and isofucosterol, while the late winter-early spring period displayed close relationships between some saturates as well as monoenes (18:0, 18:1 $1 \omega 9,20: 1 \omega 9,22: 1 \omega 9)$ and cholesterol. Post-bloom decay associated another group of saturates and monoenes $(14: 0,20: 0,22: 0,16: 1 \omega 9,16: 1 \mathrm{t} \Delta 3)$ and $\beta$-sitosterol. Overall particulate biochemical dynamics is discussed in terms of both phytoplankton metabolism and trophic influence for the zooplankton consumers.
\end{abstract}

\section{INTRODUCTION}

There are several ways to consider the dynamics of fatty acid and sterol production, cycling and decomposition in the marine environment. Particulate matter fatty acids and sterols can be used for tracing the origin of organic matter and are indicators of biological activity of waters (Jeffrey 1970, Gagosian 1975, Huang \& Meinschein 1976, Morris \& Culkin 1976, Boussuge et al. 1978, Goutx \& Saliot 1980, Saliot et al. 1982, De Baar et al. 1983, Volkman 1986). Indeed, it is now well established that the particular structure of marine fatty acids originates from primary producers (Ackman et al. 1964, Ackman et al. 1968, Pöhl \& Zurheide 1979) and is

\section{Present addresses:}

- UQAR-Département d'Océanographie, 310 Allée Des Ursulines, Rimouski, Québec, Canada G5L 3A1

- Technical University of Nova Scotia, Candian Institute of Fisheries Technology, PO Box 1000, Halifax, Nova Scotia, Canada B3J 2 X4 only slightly modified by planktonic consumers (Sargent 1976). Thus it is not surprising that phytoplankton species composition and environmental parameters influencing the biochemical composition of phytoplankton are key factors in controlling the changes in particulate fatty acids and to a minor extent sterols (Pöhl \& Zurheide 1979)

Marine seston is composed of different kinds of living and non-living material (Riley 1970), but most studies on fatty acids and sterols in phytoplankton have utilized cultured species (Kayama et al. 1963, Williams 1965, Kates \& Volcani 1966, Collier 1967, Ackman et al. 1968, Chuecas \& Riley 1969, Harrington et al. 1970, De Mort et al. 1972, Orcutt \& Patterson 1975, Fisher \& Schwarzengach 1978, Moreno et al. 1979, Volkman et al. 1980, Volkman et al. 1984, Nichols et al. 1984). Such studies established the influence of various environmental parameters such as light (Nichols 1965, Pöhl \& Wagner 1972, Orcutt \& Patterson 1975), temperature (Ackman et al. 1968, Paoletti et al. 1974) and nitrogen 
availability on phytoplankton biochemical composition (Miller 1962, Pohl \& Wagner 1972). However, the results of Lewis (1969), Jeffries (1970, 1972). Schultz (1974), Goutx \& Saliot (1980) and Kattner et al. (1983) clearly illustrated that natural changes in seston fatty acid composition are not only related to physiological and biochemical parameters but also to the geographical and temporal changes observed in the different categories of particles (phytoplankton, detritus, microzooplankton, bacteria, etc.) and, consequently, data derived from single species laboratory cultures cannot be directly extrapolated to natural situations.

The influence of particulate matter quality on the nutrition and energy budget of primary consumers (Richman \& Dodson 1983, Paffenhöfer \& Van Sant 1985) has shown that the definitions of food through elemental analysis or partition between a living and non-living fraction were of limited use in explaining the efficiency of food assimilation and production. Numerous studies on the influence of food composition on the metabolism of various phytoplankton-consumer species (Sandifer \& Joseph 1976, Kanazawa et al. 1977. Jones et al. 1979, Martin 1980, Teshima et al. 1983, Enright et al. 1986) have demonstrated that essential fatty acids, sterols, and vitamins are components that must be considered individually.

In the present study we consider the seasonal changes in sterol-fatty acid composition of surface particles in relation to size and to chemical parameters classically used in trophic relationship studies. Knowledge of the magnitude of such changes in a coastal environment is needed to define the framework of future work on their influence on the metabolism of planktonic grazers.

\section{MATERIAL AND METHODS}

On 14 dates between March and August 1976, water was sampled from a depth of $2.5 \mathrm{~m}$ at a central location $\left(44^{\circ} 42.3^{\prime} \mathrm{N}, 63^{\circ} 39.2^{\prime} \mathrm{W}\right)$ in Bedford Basin, Nova Scotia, Canada, using a 301 Niskin bottle. Prefiltering through $163 \mu \mathrm{m}$ bolting cloth eliminated large zooplankters and debris. Known volumes were then filtered through either prebaked $0.8 \mathrm{\mu m}$ silver filters (Selas Flotronic) for carbon and nitrogen analyses or prebaked GF/C filters for chlorophyll, protein and carbohydrate. All filters were frozen $\left(-30^{\circ} \mathrm{C}\right)$ for a few days until analysis. Particle concentrations of sizes ranging from 2.0 to $161 \mu \mathrm{m}$ equivalent diameter were estimated with a model T Coulter counter using 3 aperture tubes (100, 280 and $400 \mu \mathrm{m})$. After removal of overlaps, 20 channels were defined to cover the entire size range (Sheldon 1973). These channels are those used in the statistical analyses. Total volume was estimated from the sum of the volumes of each channel. All particle sizes refer to equivalent spherical diameters (ESD).

Particulate organic carbon and nitrogen concentrations were determined using a Hewlett-Packard F \& M 185B analyser. Particulate chlorophyll, protein and total carbohydrates were measured according to the methods described in Mayzaud \& Taguchi (1979).

Particulate matter for lipid analysis was obtained after filtration of $50 \mathrm{l}$ of seawater on chloroformextracted $\mathrm{GF} / \mathrm{C}$ filters. All samples were immediately extracted according to the method of Bligh \& Dyer (1959). After saponification according to the AOCS method Ca-6b-53 and removal of the unsaponifiable fraction, the fatty acids were recovered and converted to methyl esters by refluxing for 30 min with $7 \% \mathrm{BF}_{3}$ in methanol. A nitrogen atmosphere was maintained at all times.

Gas liquid chromatography (GLC) of methyl esters was carried out with a Perkin-Elmer model 900 chromatograph equipped with a flame ionization detector. The wall-coated open tubular (capillary) columns used were of stainless steel, $46 \mathrm{~m}$ in length $x$ $0.25 \mathrm{~mm}$ internal diameter, coated with SILAR-5 CP or Apiezon L (AP-L). The columns were operated isothermally at $170^{\circ} \mathrm{C}$ (SILAR-5CP) and $200^{\circ} \mathrm{C}$ (AP-L). Helium was used as carrier gas (Mayzaud \& Ackman 1976) at $60 \mathrm{psig}\left(=4.1 \times 10^{5} \mathrm{~Pa}\right.$ ) (SILAR-5 CP) and $80 \mathrm{psig}(=$ $\left.5.5 \times 10^{5} \mathrm{~Pa}\right)(\mathrm{AP}-\mathrm{I})$. Injector, detector and manifold temperatures were maintained at $250^{\circ} \mathrm{C}$. In addition to the examination of esters as recovered, parts of the all ester samples were completely hydrogenated and the products examined qualitatively and quantitatively by GLC. The quantitative results are given to 2 decimal places to permit the inclusion of minor components, but this does not imply this order of accuracy. Major components $(>10 \%)$ should be accurate to $\pm 5 \%$, moderate sized components ( 1 to $9 \%$ ) to $\pm 10 \%$ and minor components $(<1 \%)$ to up to $\pm 50 \%$

Sterols were isolated from the unsaponifiable fraction by thin layer chromatography on silica gel (Prekotes Adsorbosil 5, Applied Sciences Lab.) using hexane and diethylether (50:50) as a solvent system. Gas chromatography of sterols was carried out with a Perkin-Elmer model 3920 chromatograph equipped with a flame ionization detector. Analyses were run on a support-coated column (length. $2 \mathrm{~m}$, internal diameter: $2 \mathrm{~mm}$ ) packed with $3 \%$ OV.17 on Gas chrom Q 80/100 mesh. The column temperature was maintained at $240^{\circ} \mathrm{C}$ under a helium pressure of 40 psig $(2.8 \times$ $10^{5} \mathrm{~Pa}$ ). Peaks were identified by means of reference standards and their identity confirmed by GC.MS (DuPont 21-491 Mass spectrometer coupled with a Hewlett-Packard 5750 Gas chromatograph). Because the distribution of sterols was established to evaluate their natural availability to zooplankton consumers and 
not to evaluate their significance as geochemical markers, common names were used to ease comparisons with the various nutrition-oriented works. Such use does not imply specific stereochemical configurations.

Bivariate statistical analyses were first performed on size spectral and biochemical descriptions using nonparametric Spearman correlation (Conover 1980). Because of the overwhelming amount of data generated by fatty acid and particle size analyses, a global comparison of their covariation is usually not possible by classical bivariate analysis. Multivariate approaches were found more satisfactory to take into account all the interrelations between variables. Two groups of methods were used: Principal Component Analysis (PCA) following Legendre \& Legendre (1984) and Principal Component Analysis on Instrumental Variables (PCAIV) after Escoufier (1973). The analyses were performed on either the correlation matrix of arcsinetransformed fatty acid and sterol data or untransformed volume data.

The PCA method. The objective of the Principal Component Analysis is to establish the major (or principal) characteristics of a set of variables observed on a set of samples and to give a graphical representation of their similarities in a reduced dimensional space. The data are grouped in a rectangular matrix, $X$, with a number $(n)$ of columns corresponding to the samples and a number $(p)$ of rows corresponding to the variables.

The scattergram of these samples in the $p$-dimensional space defined by the initial variables (with $p>3$, in general case) cannot be viewed. By diagonalisation of the covariance or correlation matrix computed from the initial variables, we obtained a set of eigen values associated with a similar number of eigenvectors that define a new orthogonal space. The new axes are linear combinations of the initial variables and are called principal components or factors. The eigen values, given in a decreasing order of magnitude, represent the amount of variations encountered by the corresponding principal components or factors. The elements of the resulting factor loading matrix are correlations between the original variables (particle size, fatty acids) and the principal components. Factor scores which represent the contribution of the observations to the axes are calculated to have a zero mean and unit variance. The factorial axes may be interpreted using the elements of the factor loading matrix and the factor scores of the observations. Once the factorial axes, based on the 'active variables' have been extracted, 'supplementary variables', not used in the determination of the axes, may be added to the analysis. These may be located by projecting them onto the factorial plans of the first principal components derived from the active variables only. A formulation for computing sup- plementary variables may be found in Lebart et al. (1977)

Usually a limited number of principal components can be retained to explain a large proportion of the total variance. Projections of the variables or observations on the respective factorial planes may lead to the definition of groups of correlated variables or similar observations, which we will call 'multivariate groups' To be considered valid, such groups must be tight in all projections of the retained axes, and not in only one plane.

Normality of the data is not required for principal component analysis. Ibanez (1971) and Chanut et al. (1977) have noted that the ordination of the variables on the first principal component is not necessarily modified by transformations of the original data. Nevertheless, a distortion occurs if some variables have a very different dispersion from others. They have shown that stabilization of homogeneity of the variances by some appropriate transformations is sufficient to obtain consistent results. In the case of the fatty acids and sterols, since we were dealing with percentage, an arc-sine transformation was adopted.

The possible relationships between the chemical and size descriptions were established using a different multivariate approach.

The PCAIV method. The objective of the Principal Components Analysis on Instrumental Variables (the PCAIV method) is to study the associations between 2 groups of variables measured on the same lot of individuals. The data matrix can be represented under the matricial form

$$
X=\left\{\begin{array}{l}
x_{1} \\
x_{2}
\end{array}\right\}
$$

where $\mathrm{X}_{1}$ and $\mathrm{X}_{2}$ involve, respectively, $p$ and $q$ variables measured on the same set of $n$ sample units.

In contrast to the canonical analysis, the 2 groups of variables play an asymmetrical role. One group of variables, $\mathrm{X}_{2}$ for instance, selected as independent or explanatory variables (sometimes named instrumental variables; Rao 1964), is used to explain variations in the other group of variables $\left(\mathrm{X}_{1}\right.$, in present case), considered as dependent ones.

The problem is to replace the $q$ variables of $X_{2}$ by $a$ set of $m$ linear combinations of the variables $X_{2}, Z_{2}=$ $\mathrm{PX}_{2}$ (with $m \leq q$ ) in such a way that the predictive efficiency of $Z_{2}$ for $X_{1}$ is maximum. In the PCAIV method, the measure of predictive efficiency of $Z_{2}$ for $\mathrm{X}_{1}$ is made by means of a matrix correlation coefficient, the Escoufier's Rv coefficient (Escoufier 1973).

This problem can be viewed from 2 points of view. From a regression point of view, the linear combination of the variables $X_{2}$, denoted by $Z_{2}$, will be a good choice if it permits a good fit of the variables involved in the 
matrix $X_{1}$ by the variables present in the matrix $X_{2}$. In this case, variables in $X_{1}$ play the role of dependent ones whereas those in matrix $\mathrm{X}_{2}$ act as explanatory ones. From a multidimensional scaling point of view, the transformed matrix $Z_{2}$ will be a good choice if the distances between individuals or samples units generated by $Z_{2}$ are similar to those generated by $X_{1}$.

The graphical representation of the variables and individuals follows a similar principle to that of PCA. But in PCAIV, variables and individuals are plotted onto the subspace of the first principal components, deduced from linear combinations of the explanatory variables $\mathrm{X}_{2}$, only. If the variables are previously centered and standardized, 2 variables are represented by 2 vectors of unit length with the same origin and with an angle proportional to their correlation. The angle between vectors representing any variable to matrix $\mathrm{X}_{2}$ and any principal component is proportional to their correlation, and gives some indications about the contribution of this variable to the definition of the corresponding principal axis. In the case of a good prediction of the variables $X_{1}$ by $Z_{2}$, a good representation of the variables $X_{1}$ can be obtained by projecting them as supplementary variables onto the subspace defined by variables $\mathrm{X}_{2}$. Because variables of matrix $X_{1}$ have not been directly involved in the definition of the principal axis, proximities between vectors representing variables of the matrix $X_{1}$ and principal axis have no significance. But, in the presence of a high predictive efficiency of $Z_{2}$ for $X_{1}$, angles between vectors representing variables of matrices $X_{1}$ and $\mathrm{X}_{2}$ can be interpreted in terms of correlation. As in PCA, individuals or sample units can be viewed on the plan of the first principal components.

\section{RESULTS}

\section{Seasonal change in volume, size and chemical composition of the particles}

Seasonal changes in total volume of particles, particulate organic carbon and nitrogen are presented in Fig. 1b. All of these parameters display the same pattern of variation with an intense spring maximum, corresponding to the phytoplankton bloom and an early summer (June) pulse of lower amplitude. As a result, there are few changes in the $\mathrm{C}: \mathrm{N}$ ratio, which varies between 4.5 and 10 (Fig. 1a). In terms of chlorophyll (Fig. 1a), a different pattern of variation is observed since the spring peaks do not coincide with those of volume, POC and PON (9 March) and the summer maximum is shifted to early August (Fig. 1).

Examination of the particle size spectra (Fig. 2) reveals that most of the spring bloom and part of the late spring (May) and midsummer (August) periods display
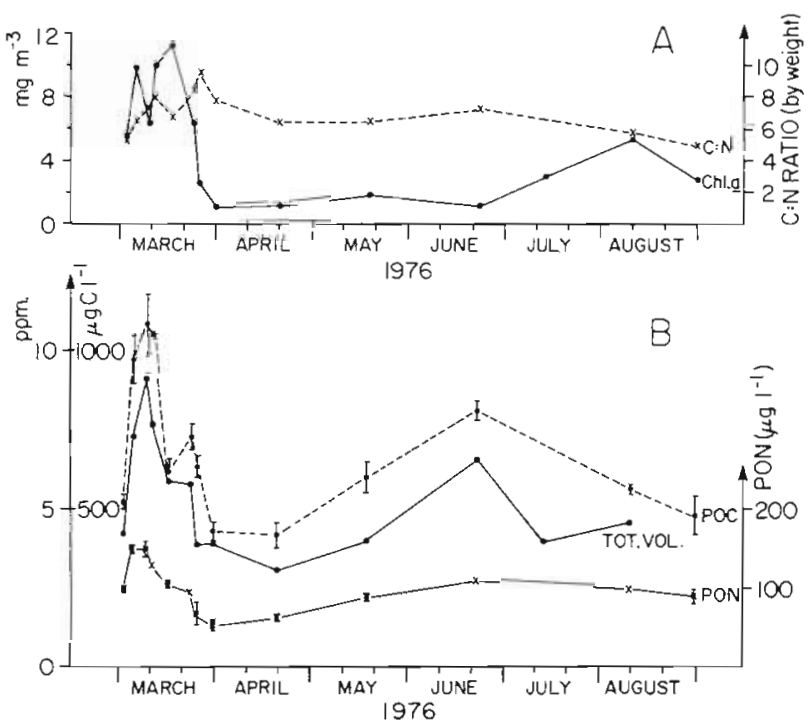

Fig. 1. Seasonal changes of (A) chlorophyll a and C:N ratio, and (B) particulate organic carbon (POC), particulate organic nitrogen (PON) and total volume of particles (TOT.VOL.) in Bedford Basin surface waters

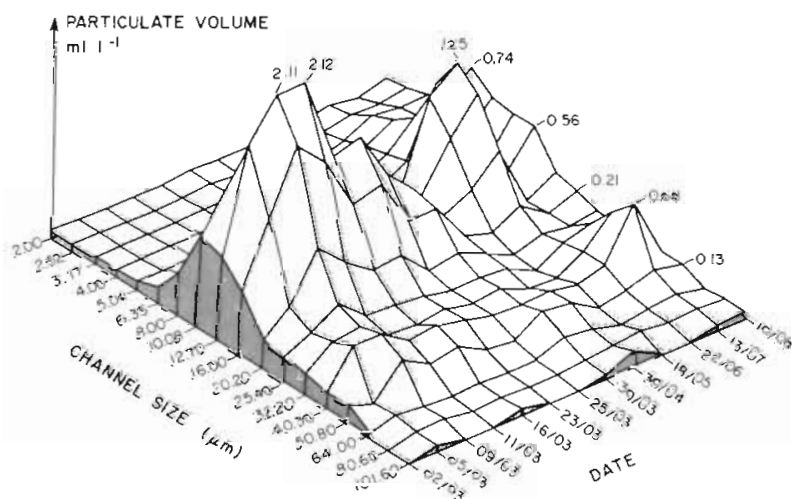

Fig. 2. Temporal variations of the particle size spectra measured with a Coulter counter

a unimodal distribution with most of the particulate volume made up by particles in the 6.35-25.4 $\mu \mathrm{m}$ range. A bimodal distribution is observed in early March, April and July with peaks in the 8.00-16.00 um and 32.0-64.0 $\mu \mathrm{m}$ range. Division of the total volume into 5 size ranges, based on a cluster analysis derived from the correlation matrix between channels, showed that: (1) in percentage the very small particles (small flagellates) hact an increasing significance as the summer developed; and (2) the spring and summer periods were characterized by successive dominance of medium sized $(12.7-25.4 \mu \mathrm{m})$, small $(8.00-10.08 \mu \mathrm{m})$ and to a minor extent large particles $(32.0-50.8 \mathrm{\mu m})$

The biochemical compositions of the particulate matter display a rather complex pattern over seasons (Fig. 3). The protein content distribution shows 2 max- 


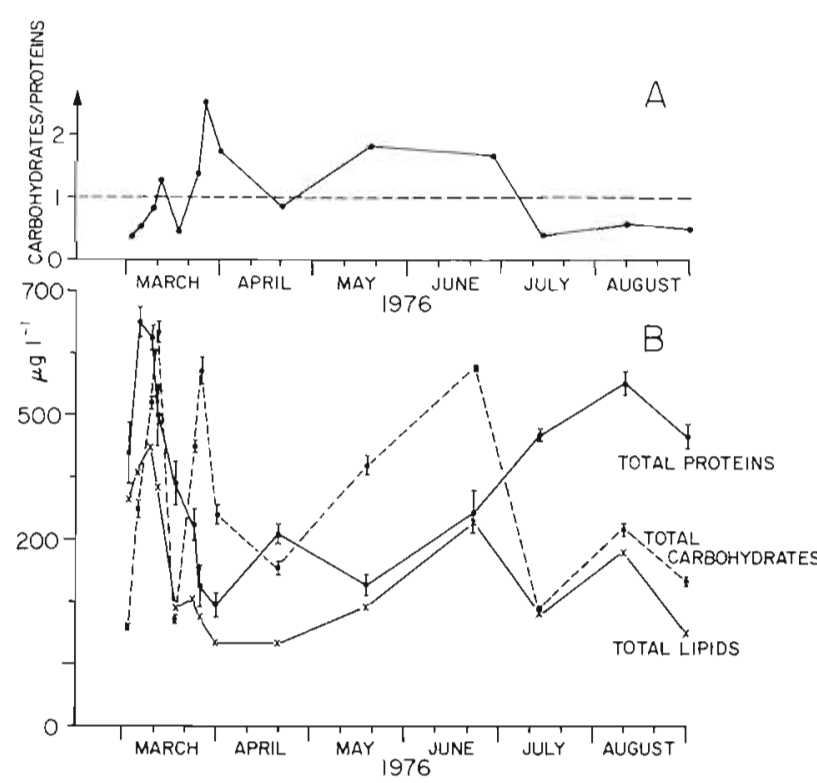

Fig. 3. Seasonal changes of (A) carbohydrate:protein ratio, and (B) total proteins, carbohydrates and lipids of particulate matter collected in Bedford Basin

ima, one very early in March, suggesting that the bloom was well under way when the sampling was initiated, and a second one during midsummer (JulyAugust). As expected, protein levels decreased sharply during March and remained at a low level during the post-bloom period. The total carbohydrate content displays a different pattern of variation with 2 maximum values during the spring, one mid-June and one midAugust. The changes in total lipids more or less followed those of proteins from March to June and those of carbohydrates during the summer. The ratio carbohydrate:protein, indicative of quality changes, shows periods of low (spring, summer) and high values (late spring, May and June).

\section{Relationships among particulate descriptors}

In order to establish the seasonal succession in terms of size and chemical characteristics, a correlation matrix was subjected to principal component analysis. The Coulter data were taken as active variables and the chemical descriptors as supplementary variates. Three axes were needed to explain $89 \%$ of the total variance (Fig. 4). Projections of all the variables on the factorial planes defined by the first 3 components (Fig. 4A, C) show that 4 'multivariate groups' can be differentiated: one corresponding to small particles $(2.0-6.4 \mu \mathrm{m})$, another corresponding to the medium size particles $(12.7-25.4 \mu \mathrm{m})$, a third corresponding to the 32.0-50.8 $\mu \mathrm{m}$ size range and one associating the total particulate volume with the carbon and nitrogen levels. From the level of correlation between the variables and the eigenvectors, it can be seen (Fig. 4A, C) that the first axis separates very small particles from the rest of the size spectrum and chemical parameters. The second axis, independent of the first, singles out the large size fraction $(64.0-101.6 \mu \mathrm{m})$, while the third one separates a group of small particles $(8.0-10.0 \mu \mathrm{m})$ and carbohydrates from the other parameters. Projections of the observation dates on the corresponding factorial planes (Fig. 4B, D) show that the first axis should be considered as a term of seasonal heterogeneity which opposes the spring bloom $(12.7-25.4 \mu \mathrm{m})$ to the summer period $(2.0-6.4 \mu \mathrm{m})$. The second axis corresponds to a factor of evolution within each group and a period of transition between groups, each characterized by spectral changes in the 8.0-10.0 $\mu \mathrm{m}$ or $64.0-101.6 \mu \mathrm{m}$ size ranges. The third axis singles out the July bimodal size spectrum with a dominant large size component (32-50.8 $\mu \mathrm{m})$. Thus, the seasonal succession observed appears to reflect mostly the quality changes irrespective of whether we consider size or chemical characteristics.

\section{Seasonal changes in fatty acid composition}

The percent distributions of fatty acids throughout the seasons are presented in Table 1 and displayed a remarkable level of stability in terms of dominant components. Saturates were the major fraction of the total and were always dominated by palmitic acid and to a lesser extent by myristic and stearic acids. Whether odd or even, the other saturated acids were present at less than $1 \%$ of the total. Branched-chain acids (iso, anteiso) were recorded most of the time but without a clear pattern of seasonal changes. Monoenes were mostly represented by palmitoleic $(16: 1 \omega 7)$ and oleic (18:1w9) acids. Cis-vaccenic acid (18:1w7) was also recorded but in relatively small percentages. C20 and C22 monoenoic acids were present at a low level and without seasonal patterns of variation. Dienes and tri-

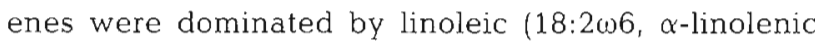
$(18: 3 \omega 3), 16: 3 \omega 6$ and $16: 3 \omega 4$ acids. Polyunsaturated acids with more than 3 double bonds were mostly represented by the $16: 4 \omega 1,18: 4 \omega 3,18: 5 \omega 3,20: 5 \omega 3$ and 22:6w3

Seasonal changes affected primarily the relative distribution of saturates (SAT), monoenes and polyunsaturated acids (PUFA). Saturates and PUFA displayed opposite behaviour. Saturates showed maximum values early in the spring bloom, late spring (May) and mid summer (August). Monoenes showed an intermediate pattern of variation with generally decreasing relative levels from spring to summer. In terms of individual fatty acids, stearic acid did not show any varia- 

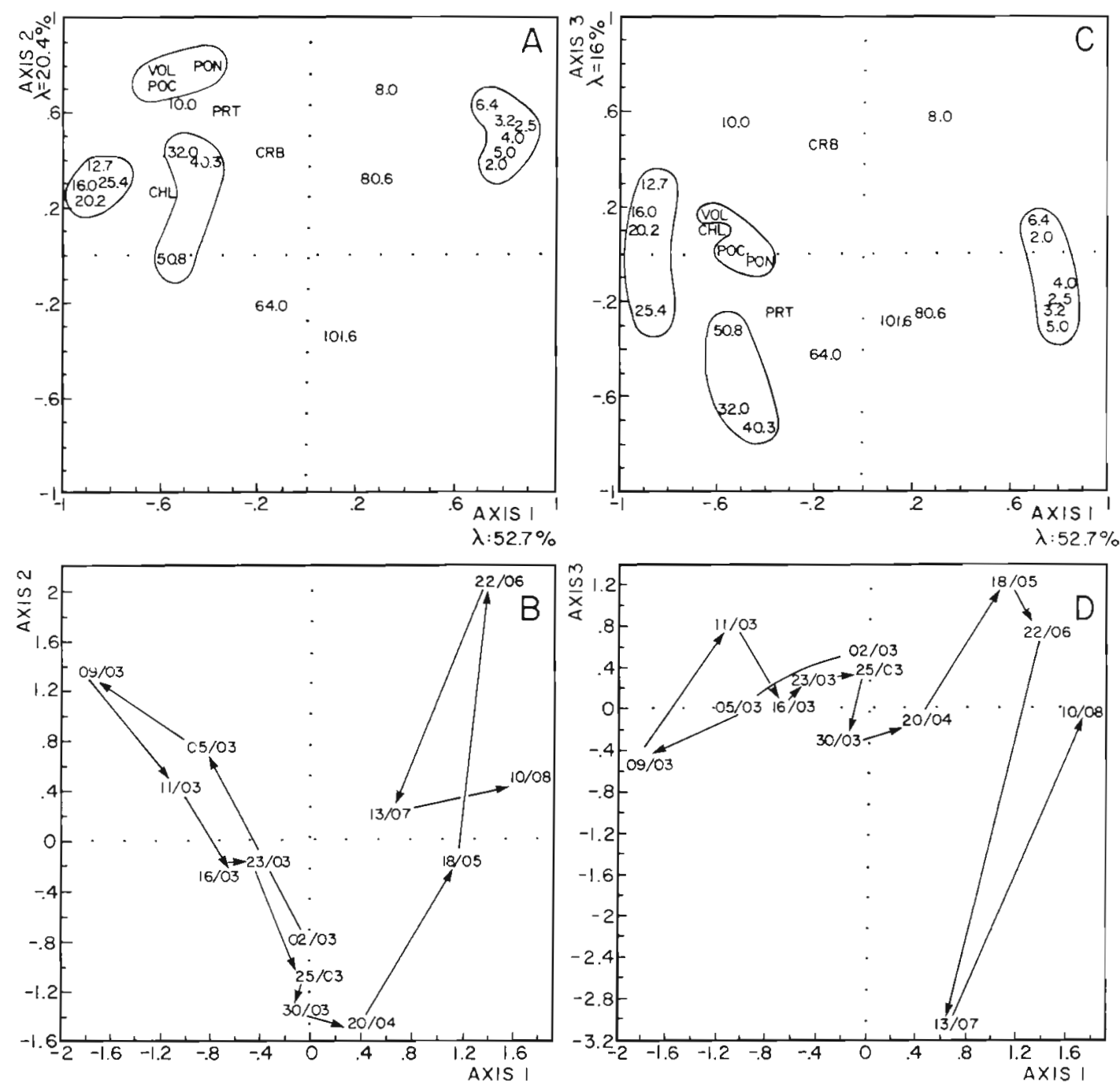

Fig. 4. Principal component analysis of the correlation matrices between particle diameters $(2.5-101.6 \mu \mathrm{m})$ with projection of the $2.0 \mu \mathrm{m}$ diameter size, chlorophyll a (CHL), total proteins (PRT), total carbohydrates (CRB), total volume (VOL), particulate organic carbon (POC) and particulate organic nitrogen (PON) as supplementary variables. (A, C) Factor loadings on the first 3 axes; (B, D) factor scores on the first 3 axes. $\lambda: \%$ total variance explained by each axis

tion over the entire period of time studied, while palmitic acid displayed minimum relative values during the bloom period and maximum during May fbloom decay). Myristic acid had an intermediate behaviour but with maximum percentages in April-May and August. Palmitoleic and oleic acids also displayed opposite patterns of changes with the spring bloom and post-bloom associated with high palmitoleic acid levels and the pre-bloom and May period associated with maximum percentages of oleic acid.

Polyunsaturated fatty acids displayed strong seasonal variability. Comparison between the pools of $\mathrm{C} 16$ and $\mathrm{C} 18$ polyunsaturates revealed different behaviours over time. C16 polyenes decreased from spring to summer and for most of the time were present in smaller percentages. The $\mathrm{C} 18$ polyenes showed 2 peaks of relative abundance at the beginning of the spring bloom and early summer. Minimum relative values were recorded at the time of the bloom decay (AprilMay). Of the 3 major PUFA $(18: 5 \omega 3,20: 5 \omega 3,22: 6 \omega 3)$ all display a similar general pattern of changes but with clear differences in their relative distributions. From the first period of the spring bloom until late spring (May) 20:503 was dominant while 18:503 and 22:6w3 remained at a low level. As the summer progressed the latter gradually became dominant.

\section{Seasonal changes in sterol composition}

In terms of sterols the particulate matter had a simpler composition with a spectrum of 10 constituents 
Table 1. Seasonal changes in 1976 in fatty acid composition of surface particulate matter lipids (expressed as \% total fatty acids). I.V.: iodine value

\begin{tabular}{|c|c|c|c|c|c|c|c|c|c|c|c|c|c|c|}
\hline Fatty acids & 2 Mar & $5 \mathrm{Mar}$ & $9 \mathrm{Mar}$ & $11 \mathrm{Mar}$ & 16 Mar & $23 \mathrm{Mar}$ & 25 Mar & $30 \mathrm{Mar}$ & $20 \mathrm{Apr}$ & 18 May & 22 Jun & $13 \mathrm{Jul}$ & $10 \mathrm{Aug}$ & 31 Aug \\
\hline \multicolumn{15}{|l|}{ Saturates } \\
\hline $14: 0$ & 8.28 & 6.29 & 9.91 & 10.06 & 7.57 & 9.51 & 11.18 & 7.33 & 15.64 & 15.17 & 10.22 & 5.73 & 14.01 & 6.37 \\
\hline iso 15 & 1.76 & 0.52 & 0.14 & 0.27 & 0.10 & 0.20 & 0.18 & 0.05 & 0.82 & 0.57 & 0.51 & 0.85 & 0.61 & 0.53 \\
\hline A iso 15 & 0.59 & 0.42 & 0.03 & 0.24 & 0.23 & 0.35 & 0.43 & 0.27 & 1.07 & 0.65 & 0.57 & 0.85 & 0.50 & 0.71 \\
\hline $15: 0$ & 1.86 & 1.04 & 0.90 & 1.01 & 1.11 & 1.21 & 1.13 & 1.04 & 2.06 & 1.13 & 0.82 & 0.70 & 0.85 & 0.98 \\
\hline iso $16: 0$ & 0.01 & 0.41 & 0.65 & 0.40 & 0.59 & 0.06 & 0.30 & 0.16 & 0.16 & 0.32 & 0.15 & 0.38 & 0.25 & 0.13 \\
\hline$A$ iso $16: 0$ & - & - & - & - & - & 0.15 & 0.27 & 0.13 & - & 1.50 & 0.16 & 0.15 & 0.31 & 0.35 \\
\hline iso $17: 0$ & 0.19 & 0.20 & 2.64 & 1.32 & - & 0.59 & - & - & - & 0.04 & - & 0.15 & 0.37 & - \\
\hline A iso $17: 0$ & 0.19 & 0.10 & - & - & 0.08 & - & - & 0.08 & - & 0.12 & 0.06 & 0.08 & 0.37 & 0.02 \\
\hline Pristanate & 0.15 & 0.40 & 0.43 & 0.78 & 0.60 & 0.73 & 0.20 & 0.36 & 0.16 & 0.54 & 0.18 & 0.15 & 0.12 & 0.09 \\
\hline $16: 0$ & 23.21 & 15.82 & 17.09 & 18.93 & 15.78 & 14.36 & 20.72 & 19.66 & 23.01 & 28.48 & 16.04 & 19.85 & 20.99 & 17.96 \\
\hline $17: 0$ & 1.53 & 0.90 & 0.55 & 0.40 & 0.89 & - & 0.68 & 1.18 & 0.91 & 0.63 & 0.71 & 0.90 & 0.84 & 0.46 \\
\hline Phytanate & -. & - & - & - & - & - & - & - & - & - & - & - & - & - \\
\hline iso $18: 0$ & 0.05 & 0.10 & 0.07 & 0.02 & 0.03 & 0.02 & 0.15 & - & 0.04 & 0.04 & - & - & - & 0.04 \\
\hline $18: 0$ & 8.53 & 4.89 & 3.55 & 3.27 & 4.57 & 3.89 & 3.31 & 4.75 & 4.28 & 5.84 & 1.95 & 2.64 & 4.13 & 4.83 \\
\hline 19:0 & 0.16 & - & 0.12 & 0.21 & 0.09 & 0.12 & 0.06 & 0.08 & 0.04 & 0.04 & 0.09 & - & 0.06 & - \\
\hline $20: 0$ & 0.12 & 0.22 & 0.17 & 0.14 & - & 0.26 & 0.26 & 0.33 & 0.33 & 0.38 & 0.08 & 0.15 & 0.21 & 0.25 \\
\hline $21: 0$ & 0.16 & 0.10 & - & - & - & - & - & 0.08 & - & - & - & - & - & - \\
\hline $22: 0$ & 0.28 & 0.34 & 0.69 & 0.63 & 0.50 & 0.50 & 0.46 & 0.70 & 0.52 & 0.34 & 0.56 & 0.42 & 0.45 & 0.28 \\
\hline $24: 0$ & 0.07 & - & - & - & 0.28 & 0.26 & - & - & - & - & - & - & - & 0.12 \\
\hline \multicolumn{15}{|l|}{ Monoenes } \\
\hline $15: 1 \omega 8$ & 0.68 & - & 0.21 & 0.40 & 0.44 & 0.15 & 0.45 & 0.34 & 0.41 & 0.40 & 0.28 & 0.15 & 0.28 & 0.13 \\
\hline $16: 1 \omega 9$ & 1.72 & 0.92 & 0.27 & 1.32 & 0.71 & 1.48 & 1.43 & 2.09 & 3.07 & 1.27 & 0.99 & 1.22 & 1.61 & 1.22 \\
\hline $16: 1 \omega 7$ & 0.86 & 10.79 & 18.38 & 21.12 & 17.75 & 23.11 & 25.76 & 21.88 & 18.59 & 5.39 & 13.40 & 3.35 & 4.95 & 5.75 \\
\hline $16: 1 \omega 5$ & - & - & - & - & - & 3.56 & 1.19 & 0.94 & 1.29 & 0.95 & 1.36 & 1.68 & 1.86 & 1.74 \\
\hline $17: 1 \omega 8$ & 0.47 & 0.20 & 0.20 & 0.18 & - & - & 0.27 & 0.21 & 0.56 & 0.16 & 0.09 & 0.15 & 0.15 & 0.06 \\
\hline $18: 1 \omega 9$ & 16.89 & 6.98 & 4.58 & 5.63 & 7.95 & 5.35 & 4.50 & 6.72 & 6.42 & 12.81 & 4.77 & 4.52 & 5.73 & 9.32 \\
\hline $18: 1 \omega^{7}$ & 1.88 & 1.75 & 1.22 & 1.62 & 1.79 & 2.03 & 1.91 & 2.46 & 3.17 & 3.49 & 2.10 & 3.06 & 2.43 & 3.50 \\
\hline $18: 1 \omega 5$ & - & - & - & - & 0.25 & 0.22 & - & 0.26 & - & 0.54 & 0.26 & 0.34 & 0.30 & - \\
\hline $20: 1 \omega 11$ & 2.79 & - & - & - & - & - & - & 0.46 & - & 3.07 & 0.36 & 0.43 & 0.41 & 0.04 \\
\hline $20: 1 \omega 9$ & 2.88 & 0.89 & 0.36 & 0.82 & 1.72 & 0.50 & 0.43 & - & 0.33 & 0.50 & - & - & 0.24 & 0.24 \\
\hline $20: 1 \omega 7$ & 0.46 & 0.02 & 0.20 & 0.30 & 0.30 & 0.10 & 0.19 & 0.86 & - & - & - & 0.17 & 0.17 & 0.04 \\
\hline $22: 1 \omega 11+13$ & 1.14 & 0.68 & 0.18 & 0.52 & 0.95 & 0.21 & 0.20 & 0.20 & 0.29 & 3.80 & 0.21 & 0.10 & 0.12 & - \\
\hline $22: 1 \omega 9$ & 3.38 & 0.71 & 0.23 & 0.41 & 2.03 & 0.66 & 0.43 & 0.34 & - & - & - & - & 0.12 & - \\
\hline $24: 1$ & 0.17 & - & - & - & - & - & - & - & - & 1.62 & 1.16 & 1.48 & - & 1.04 \\
\hline \multicolumn{15}{|l|}{ Dienes } \\
\hline $16: 2 \omega 6$ & - & - & - & - & 0.55 & 0.49 & - & - & - & 0.08 & 0.09 & 0.15 & - & 0.01 \\
\hline $16: 2 \omega 4$ & 0.47 & 1.13 & 1.96 & 2.01 & 2.00 & 2.74 & 1.18 & 0.88 & 1.02 & - & 0.78 & 0.21 & 0.34 & 0.37 \\
\hline $18: 2 \omega 6$ & 3.10 & 2.99 & 2.58 & 1.68 & 1.94 & 1.50 & 1.45 & 1.74 & 1.43 & 2.31 & 5.17 & 4.52 & 5.40 & 2.56 \\
\hline $20: 2 \omega 6$ & - & - & - & - & 0.15 & -- & - & - & - & - & 0.12 & 0.15 & 0.06 & 0.04 \\
\hline \multicolumn{15}{|l|}{ Trienes } \\
\hline $16: 3 \omega 6$ & 0.09 & 1.51 & 1.59 & 0.91 & 0.90 & 1.08 & 0.71 & 0.57 & 0.25 & - & 0.31 & 0.57 & 0.24 & - \\
\hline $16: 304$ & - & 1.01 & 1.38 & 1.05 & 1.61 & 1.56 & 1.00 & 0.88 & - & 0.27 & 0.37 & 0.34 & - & 0.47 \\
\hline $16: 3 \omega 3$ & 0.66 & - & - & - & - & - & - & - & - & - & - & 0.15 & 0.12 & 0.26 \\
\hline $18: 3 \omega 6$ & 0.02 & 0.05 & 0.27 & 0.17 & 0.31 & 0.22 & 0.31 & 0.24 & - & 0.16 & 0.39 & 0.28 & 0.22 & 0.24 \\
\hline $18: 3 \omega 3+3 \omega 4$ & 1.59 & 2.36 & 1.24 & 0.81 & 0.42 & 0.49 & 0.56 & 0.66 & 0.50 & 1.08 & 2.84 & 5.52 & 5.48 & 4.79 \\
\hline $20: 3 \omega 3$ & 0.15 & & - & - & - & - & - & - & - & - & - & 0.20 & 0.13 & 0.07 \\
\hline \multicolumn{15}{|c|}{ Polyenes with 4} \\
\hline $16: 4 \omega 3$ & 0.01 & - & - & - & 0.57 & - & 0.22 & - & - & 0.47 & 0.58 & 2.41 & 0.52 & 2.09 \\
\hline $16: 4 \omega 1$ & 1.22 & 3.19 & 4.68 & 3.88 & 4.23 & 4.24 & 3.24 & 2.87 & 1.58 & - & 1.95 & - & - & 0.73 \\
\hline $18: 4 \omega 3$ & 2.77 & 6.62 & 5.17 & 3.97 & 2.95 & 2.49 & 2.64 & 3.17 & 1.40 & 1.49 & 5.35 & 9.38 & 6.77 & 9.25 \\
\hline $20: 4 \omega 6$ & 1.18 & - & - & - & - & - & 0.16 & 0.24 & - & - & 0.41 & 0.28 & 0.19 & 0.30 \\
\hline $20: 4 \omega 3$ & 0.20 & 0.15 & - & 0.18 & 0.24 & 0.30 & 0.58 & 0.19 & 0.37 & - & 0.44 & 0.32 & 0.15 & 0.38 \\
\hline \multicolumn{15}{|c|}{ Polyenes with 5} \\
\hline $18: 5 \omega 3$ & 0.62 & 6.07 & 2.96 & 2.64 & 1.24 & 0.85 & 1.33 & 1.97 & 1.18 & 1.64 & 3.25 & 7.91 & 4.80 & 4.64 \\
\hline $20: 5 \omega 3$ & 2.75 & 11.10 & 10.59 & 8.28 & 9.16 & 8.36 & 6.48 & 6.65 & 3.56 & 0.53 & 10.51 & 6.72 & 4.92 & 7.21 \\
\hline $21: 5 \omega 3$ & 0.56 & - & - & - & 0.38 & - & - & - & - & - & 0.15 & 0.07 & 0.09 & - \\
\hline $22: 5 \omega 3$ & 1.65 & - & 0.04 & - & - & 0.51 & 0.27 & 0.64 & 0.33 & 0.43 & - & - & 0.19 & 0.92 \\
\hline \multicolumn{15}{|c|}{ Polyenes with 6} \\
\hline $22: 6 w 3$ & 2.07 & 8.07 & 4.34 & 3.40 & 4.02 & 4.07 & 2.88 & 4.31 & 2.48 & 0.94 & 9.30 & 9.46 & 6.45 & 8.80 \\
\hline I.V. & 90.47 & 178.99 & 153.74 & 131.67 & 134.39 & 135.28 & 115.27 & 125.15 & 80.50 & 99.19 & 170.53 & 184.26 & 136.85 & 174.69 \\
\hline
\end{tabular}




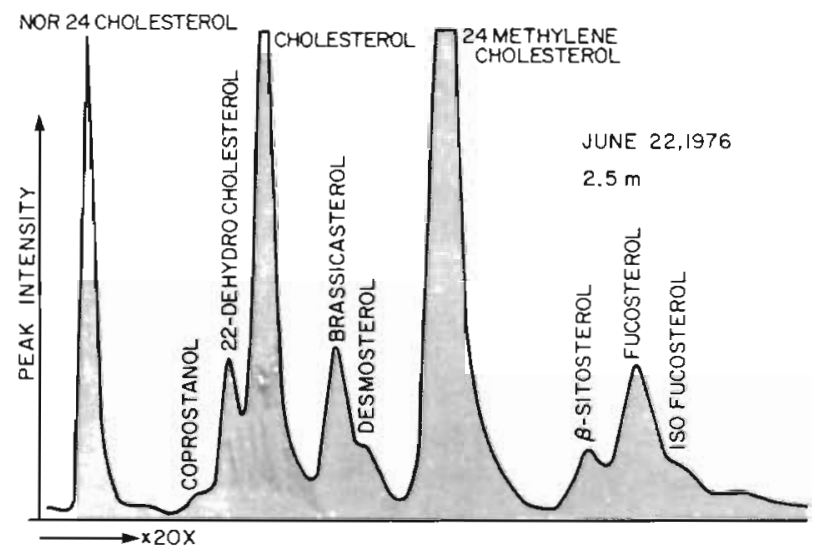

Fig. 5. Typical distribution of sterols from surface particulate matter collected in Bedford Basin

(Fig. 5). The major fractions consisted of cholesterol and 24-methylenecholesterol while nor-24-cholesterol, coprostanol, 22-dehydrocholesterol, brassicasterol, desmosterol, sitosterol and fucosterol were always minor components. The percentages of the various sterols showed relatively strong seasonal changes (Fig. 6A, B) with cholesterol and 24-methylenecholesterol following a similar pattern of variation during the

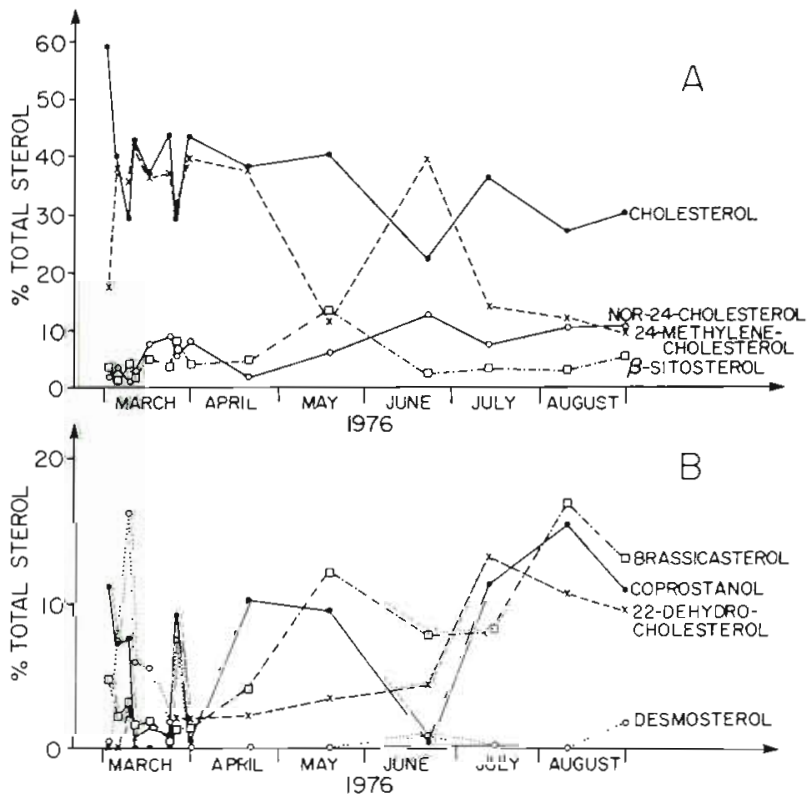

Fig. 6. Temporal variations of surface particulate sterols from Bedford Basin

spring and opposite changes at the beginning of the bloom and most of the summer (May to August). Nor24-cholesterol, coprostanol, 22-dehydrocholesterol and brassicasterol displayed increasing percentages throughout spring and summer. The spring bloom was characterized by the dominance of cholesterol, 24- methylenecholesterol and desmosterol. The postbloom decay period (May) showed high levels of cholesterol, sitosterol, coprostanol and brassicasterol. The summer period was more variable with an early phase (June) characterized by a peak of 24-methylenecholesterol and nor-24-cholesterol, and the rest (July, August) characterized by increasing percentages of cholesterol, brassicasterol, coprostanol and 22-dehydrocholesterol.

\section{Analysis of temporal changes in fatty acids}

To understand the seasonal successions as described by the fatty acid characteristics, a correlation matrix was performed and subjected to principal component analysis (PCA). Fourteen major acids were taken as active variables and the rest as supplementary variates. Three principal components were needed to explain $85 \%$ of the total variance. The first 2 axes account respectively for $39.3 \%$ and $33.5 \%$ of the inertia and the third axis for $12.7 \%$. From the levels of correlation between variables and the principal components, it can be seen that the first axis (Fig. 7A) separates some polyunsaturated acids $(22: 6 \omega 3,18: 5 \omega 3,18: 4 \omega 3$, $16: 4 \omega 3,18: 3 \omega 3,18: 2 \omega 6)$ from saturates and some monoenes $(14: 0,15: 0,16: 0,18: 0,15: 1 \omega 8,16: 1 \omega 9$, $17: 1 \omega 8,22: 1 \omega 11+13)$. Both groups are respectively representative of the summer particle production and the times of low productivity (2 March, April-May) (Fig. 7B). The second axis separates the unsaturated acids at 16 carbons and 20:5w3 from some of the

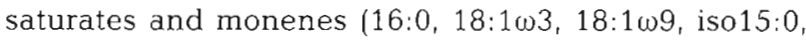
anteiso 15:0) (Fig. 7A). They single out the spring bloom ( 9 to 25 March) in opposition to the other hydrobiological periods (late spring, summer) (Fig. 7B). The third axis contrasts the 2 periods of low productivity (Fig. 7D): 2 March (early spring bloom) and 20 April (bloom decay) associated respectively with 18:0, $18: 1 \omega 9,20: 1 \omega 9,22: 1 \omega 9$ on the one hand and 14:0, 20:0 $22: 0,16: 1 \omega 9,16: 1 \mathrm{t} \Delta 3$ on the other hand (Fig. 7C). The fatty acid descriptors clearly show seasonal successions which can be related to both species successions and growth characteristics

The relative similarity of the seasonal structure defined by PCA for both Coulter and fatty acid data led us to compare both sets of data using a different multivariate approach, i.e. principal component analysis with instrumental variables. A correlation matrix of the fatty acid (arc-sine transformed) and the Coulter and biochemical data $[\log (x+1)$ transformed] was prepared using only the 20 more abundant fatty acids. The first 3 axes explained $76 \%$ of the total variance and the projections on the first 2 factorial plans are presented in Fig. 8A, B with several 'multivariate groupings'. As 

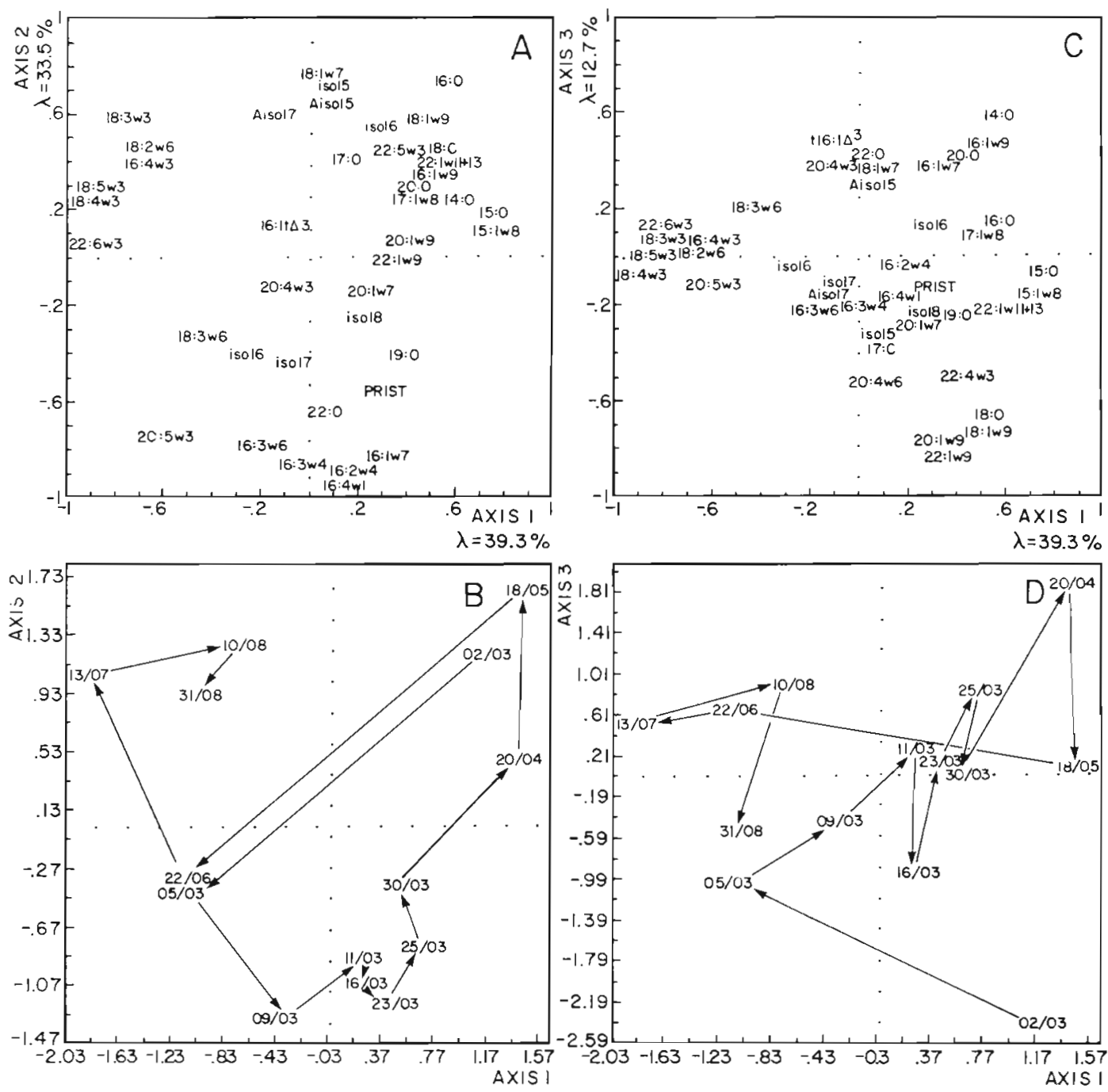

Fig. 7. Principal component analysis of the correlation matrices between fatty acids. (A, C) Factor loadings on the first 3 axes; (B, D) factor scores on the first 3 axes. $\lambda$ : \% total variance explained by each axis. PRIST pristanate; Aiso: anteiso

expected the correlations between the variables and the principal components do not show any major changes from those observed earlier. Nevertheless, the different groupings showed close associations between: very small particles $(2.0-6.4 \mu \mathrm{m})$, characteristic of summer, and one group of polyunsaturated acids $(16: 4 \omega 3,18: 3 \omega 3,18: 4 \omega 3,18: 5 \omega 3,22: 6 \omega 3)$; medium sized particles $(12.7-20.2 \mu \mathrm{m})$, characteristic of the spring bloom, and the C16 fatty acids (16:0, 16:107,

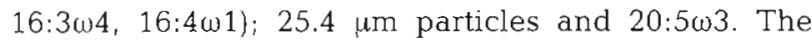
periods of low productivity (2 March, April-May) do not show clear associations except on the third axis where saturated acids $(14: 0,20: 0)$ and large particles $(80.6 \mu \mathrm{m})$ show maximum negative correlations with the third principal component.

\section{Analysis of temporal changes in particulate sterols}

Using the same multivariate procedure, it is possible to visualize the seasonal cycle of the particulate matter as defined by the covariations of the sterols (arc-sine transformed) as well as their relationships with the size spectra of particles. As plotted in Fig. 9B, D, the first axis contrasts the spring bloom to the summer period, the second axis early spring ( 2 March) to early summer (June) and the third axis the initial phase of the spring bloom (5,9 March) and the late phase and post-bloom periods (30 March, May). The resulting seasonal succession appears slightly more complicated than the one defined by the fatty acids with a certain discrimination within the spring bloom. In terms of sterols, the projec- 


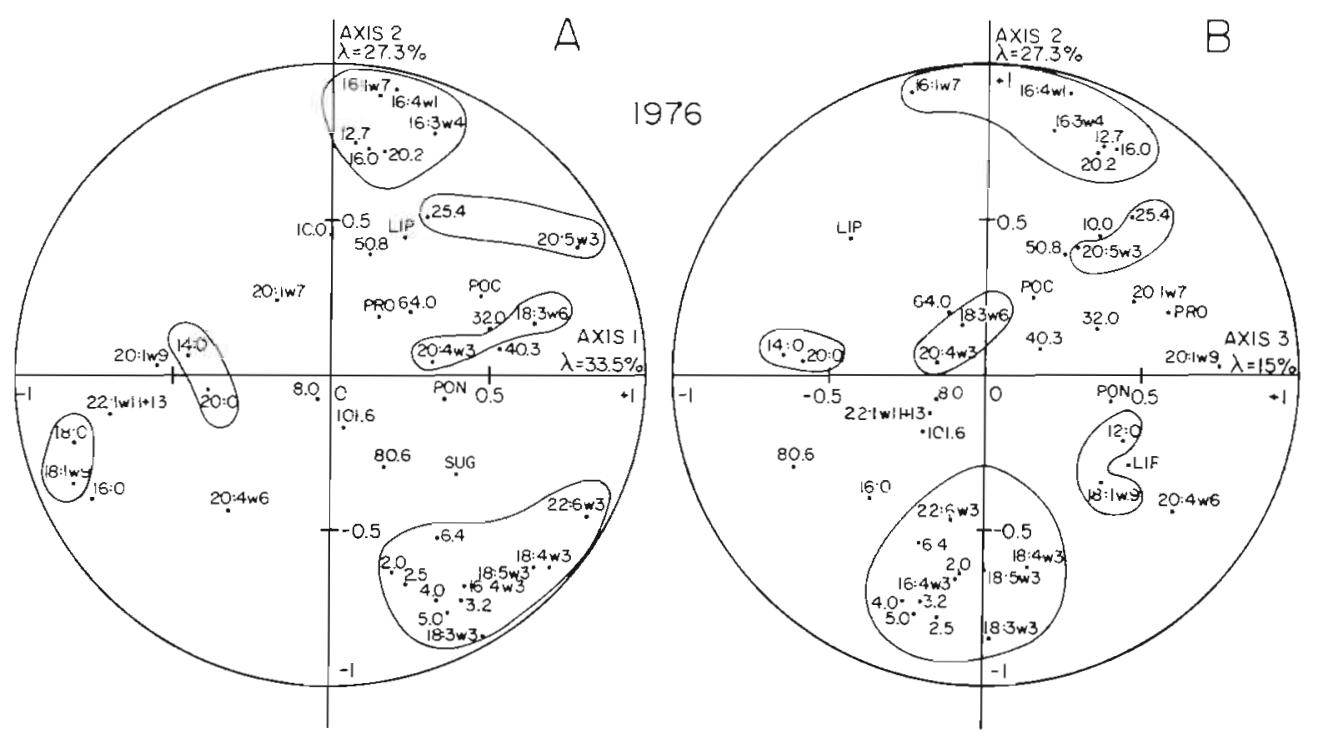

Fig. 8. Principal component analysis with instrumental variables of log-transformed Coulter and biochemical composition data and arc-sine transformed fatty acid data. (A, B) Factor loadings on the 3 axes. $\lambda$ : total variance explained by each axis. LIP: lipids; POC:particulate organic carbon; PON: particulate organic nitrogen; PRO: protein; SUG: sugars

tions on the same factorial planes (Fig. 9A, C) associate: 22-dehydrocholesterol, and to a minor extent nor-24cholesterol, with very small particles $(2.0-6.4 \mu \mathrm{m})$ and summer periods. Brassicasterol, stigmasterol and coprostanol should also be associated with the summer periods as they define negatively the first axis. They also associate 24-methylenecholesterol with mediumsmall particles $(12.7-25.4 \mu \mathrm{m})$, desmosterol with medium-large particles $(32.0-50.8 \mu \mathrm{m})$ and both with the spring bloom. Cholesterol as well as sitosterol seems related to the periods of low productivity preand post-bloom. Fucosterol is associated to the June period (high positive correlation with Axis 2) but not with any specific particle size

\section{DISCUSSION}

The seasonal successions of the various types of particles in Bedford Basin have been detailed either during the spring bloom (Conover 1975, Conover \& Mayzaud 1984), or during summer (Mayzaud \& Taguchi 1979) or throughout the entire year (Poulet 1974, Taguchi \& Platt 1978a, b, Mayzaud et al. 1984). They were derived from surveys carried out from 1973 to 1977 and showed a high level of reproducibility and similarity. Spring bloom production was usually initiated by small forms such as flagellates, dinoflagellates (Gonyaulax, Gymnodinium, Peridinium) and solitary diatoms (Chaetoceros septentrionale, Thalassionema nitschioides, etc.). As the bloom progressed, the dominant small phytoplankton was progressively replaced by larger chain-forming diatoms (Thalassiosira nordenskioldii, Chaetoceros affinis, Skeletonema costatum, etc.) and microzooplankton. During the post-bloom period a shift towards larger detrital particles was usually observed (Mayzaud et al. 1984). After the summer stratification, production was supported by a complex mixture of particles dominated by small flagellates, dinoflagellates, pulses of diatoms (Rhizosolenia delicatula, Skeletonema costatum) and microzooplankton (Poulet 1974, Mayzaud \& Taguchi 1979). Flagellates, small diatoms and dinoflagellates dominated the first part of the bloom in the present study while other diatoms ( $T$. nordenskioldii, Thalassionema fluviatilis, etc.) were abundant during the rest of the bloom. The post-bloom and summer periods were fairly similar to those described by Mayzaud et al. (1984) and Mayzaud $\&$ Taguchi (1979) for the same location.

Because seston is a mixture of particles of various origins, each with different dynamics of variation, natural size spectra are useful to characterize the seasonal or spatial successions (Sheldon et al. 1972, Chanut \& Poulet 1979, 1982, Mayzaud et al. 1984, Poulet et al. 1986). The various size groups and their related seasonal patterns were similar to those observed by Poulet (1974) and Mayzaud et al. (1984), or 1 yr later by Conover \& Mayzaud (1984) for the same environment. The major differences concerned the lesser contribution of large colonial diatoms (40 to 50 um ESD) during the spring bloom. The results of the principal component analysis revealed that the overall seasonal changes in size spectra proceeded according to a double loop-like pattern resulting from a double 


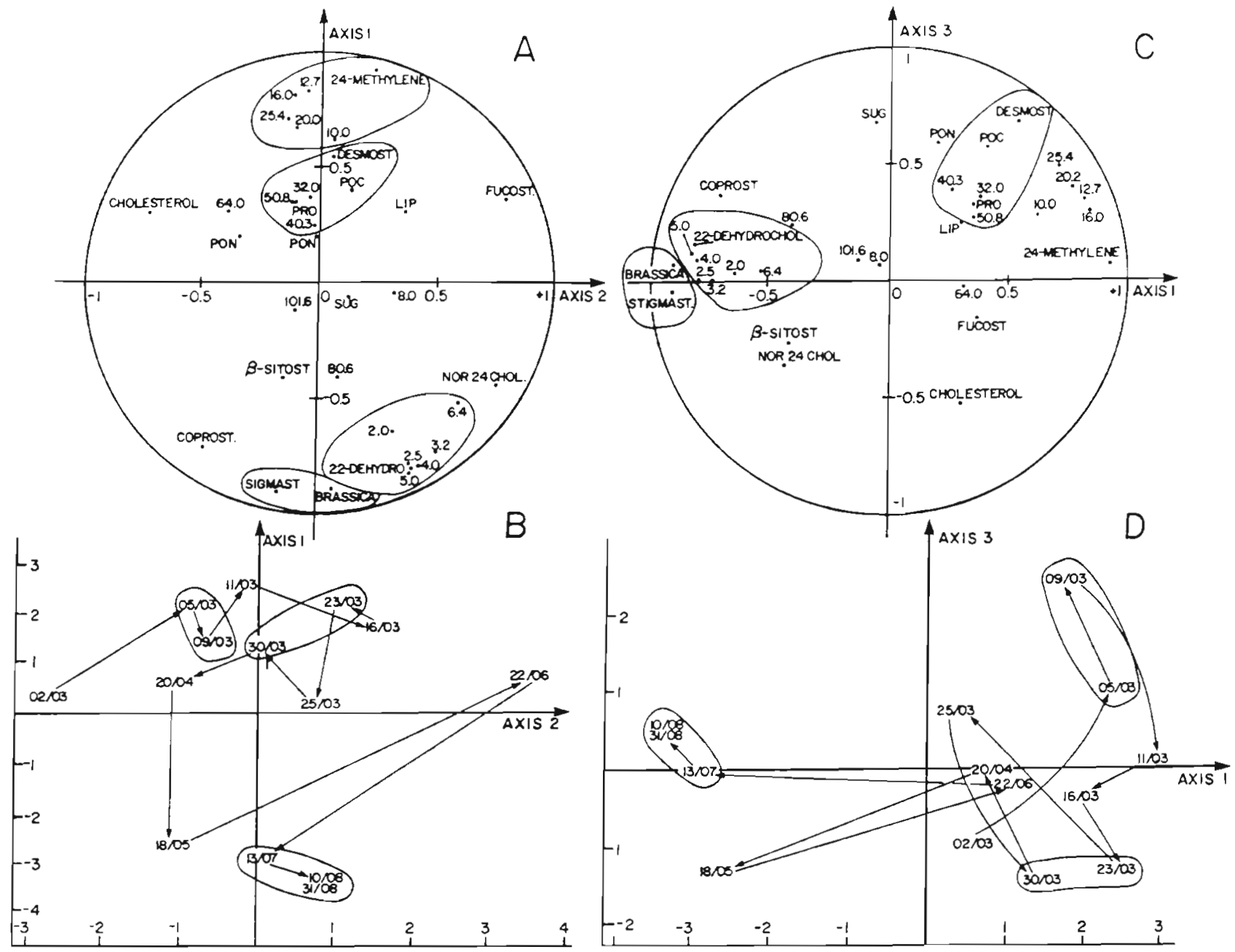

Fig. 9. Principal component analysis with instrumental variables of log-transformed Coulter and biochemical data and arc-sine transformed fatty acid data. (A, C) Factor loadings on the first 3 axes; (B. D) factor scores on the first 3 axes. 24-METHYLENE: 24methylenecholesterol; DESMOST: desmosterol; FUCOST: fucosterol; $\beta$-SITOST: $\beta$-sitosterol; NOR-24-CHOL: nor-24-cholesterol; COPROST coprostanol; STIGMAST stigmasterol; BRASSICA: brassicasterol; 22-DEHYDRO: 22-dehydrocholesterol; ISOFUCOST isofucosterol. For other abbreviations, see Fig. 8

size opposition of the first 2 principal components. Such a feature was already identified in the data presented by Mayzaud et al. (1984) for the 1974 period but not in those presented by Conover \& Mayzaud (1984), where the beginning and end of the 1977 spring bloom showed different size characteristics.

Changes in the biochemical composition were also representative of both quantity and quality changes of the particulate matter. When considering complex assemblages, such as natural seston, the variability in composition is not only related to the types of particle (phytoplankton, microzooplankton, detritus, etc.) but also to their physiological state. The difference between exponentially growing and nutrient-deficient phytoplankton has been described several times in terms of carbon, nitrogen, phosphorus and glucans
(Antia et al. 1963, Eppley et al. 1973, Haug et al. 1973, Sakshaug \& Myklestad 1973, Perry 1976, Sakshaug et al. 1981, 1983) and relies on the interpretation of the C: $N$ ratio as well as the glucan; protein ratio (Haug et al. 1973, Sakshaug et al. 1983, Ganf et al. 1986). For populations dominated by diatoms, a $\mathrm{C}: \mathrm{N}$ ratio well above 7 and a carbohydrate:protein ratio above 1 should be representative of nitrogen deficiency. On this basis, nutrient limitation occurred twice during the spring bloom (11 and $25 \mathrm{March}$ ) and, as expected, was especially severe at the end $(\mathrm{C}: \mathrm{N}=9.5$; Carb: Prot $=$ 2.6). This can be related to the consumption of nitrate which reached $88 \%$ of the initial level after the 9 th day and $100 \%$ after the 22 nd day (Irwin \& Platt 1978). Interpretation of the later spring and summer increases of the carbohydrate:protein rates (not followed by par- 
allel changes in the $\mathrm{C}: \mathrm{N}$ ratio) is made more difficult by the changes in community structure, thermal regime and nutrient supply but seem to indicate a mature population (high carbohydrate and lipid levels).

The pattern of lipid accumulation during the spring bloom showed some similarities with those observed by Morris (1984) and Morris et al. (1985) in an enclosed experimental ecosystem and by Parrish (1987) for a natural bloom. Total lipid peaks occurred respectively 4 and $7 \mathrm{~d}$ after the 2 chlorophyll maxima but dropped rapidly at the end of the bloom rather than maintaining a high level throughout the early post-bloom period (Morris et al. 1985, Parrish 1987). No relationship could be established between total lipid content and nutrient limitation in contrast with the early findings of Fogg (1956) or Badour \& Gergis (1965) and the recent observations by Parrish (1987). To what extent this is related to the 'non-systematic influence of environmental factors' reported by Shifrin \& Chisholm (1981) remains to be verified but such an effect seems likely. Throughout the entire period surveyed, the changes in particulate lipid content appear to follow the protein changes, indicating a close relationship with biological productivity. The lower summer increase, as compared to protein, should be related to the presence of microzooplankton which is a common feature of stratified waters in this basin during summer (Mayzaud \& Taguchi 1979). Seasonal changes in lipid classes were not considered in our study but have been reported to follow variable patterns depending on the year and the location considered. In an experimental enclosure acylglycerol dominated periods of low production while polar lipid characterized time of maximum exponential growth (Morris 1984, Morris et al. 1985). A more complex pattern of changes seems more appropriate to describe the natural Bedford Basin situation as Parrish (1987) did not find such clear-cut succession. Triglycerides dominated after the time of the chlorophyll maximum but were abundant at all times and displayed a pattern of changes similar to that of phospholipids.

Very few studies have been concerned with the seasonal changes in natural particulate fatty acids (Jeffries 1970, 1972, Shultz 1974, Goutx \& Saliot 1980). Some studies have focussed their attention on the spring bloom period, either under natural conditions (Kattner et al. 1983) or in experimental ecosystems (Morris 1984 Morris et al. 1985), but most have been concerned with the regulation of fatty acid biosynthesis in laboratory culture (cf. reviews by Wood 1974 and Pöhl \& Zurheide 1979). The fatty acid compositions recorded in the present study are similar to those described for phytoplankton-dominated populations. Myristic (14:0) and palmitic acids (16:0) were usually dominant with 15:0, 19:0, 20:0 and 22:0 in very small proportions. Pal- mitoleic $(16: 1 \omega 7)$ and oleic $(18: 1 \omega 9)$ acids also dominated but at specific periods in the season. Cis-vaccenic acid $(18: 1 \omega 7)$, iso $15: 0$ and anteiso 15:0, which are usually considered as bacterial markers (Morris et al. 1985), were always minor but displayed a seasonal pattern with maximum relative concentrations during the post-bloom and summer periods. Polyunsaturated acids showed strong seasonal changes with 5 major fatty acids: $16: 4 \omega 1, \quad 18: 4 \omega 3, \quad 18: 5 \omega 3, \quad 20: 5 \omega 3$ and 22:6w3.

The seasonal changes in fatty acids are usually related to the combined influence of environmental factors such as light, nutrient deficiency, temperature, etc. (Pöhl \& Zurheide 1979), species successions and physiological state (Kattner et al. 1983, Morris et al. 1985). Sorting out those fatty acids most representative of each of these influences is made difficult by the number of covariations involved. Principal component analysis illustrates the seasonal successions as defined by the fatty acid data and leads to the definition of groups of acids with similar behaviour which can be interpreted in terms of probable regulatory factors. Although the analysis does not imply causal relationship, the large body of literature on fatty acid metabolism in microalgae can be used to draw independent conclusions on whether the statistical groupings are random or representative of specific biological events. Results showed that most of the variance associated with the fatty acid changes is related to the physiological state of the populations and the species successions. Indeed, the first 2 axes discriminated, on the one hand, against the periods of high (spring bloom, summer) and low production (pre- and post-bloom) and, on the other hand, the successions between diatoms (spring bloom) and summer flagellates (dinoflagellates, naked flagellates). As expected, healthy growing populations were associated with the PUFA while the periods of minimum growth or decay were associated with the saturates $(14: 0,15: 0,16: 0,17: 0,18: 0)$, some monoenes $(15: 1 \omega 8, \quad 16: 1 \omega 9, \quad 17: 1 \omega 8, \quad 18: 1 \omega 9, \quad 18: 1 \omega 7, \quad 20: 1 \omega 9$, $22: 1 \omega 9,22: 1 \omega 11+13$ ) and the iso, anteiso acids (iso 15:0, anteiso $15: 0$, anteiso $17: 0$, iso 16:0). Following the results obtained with cultured species (cf. reviews by Pöhl \& Zurheide 1979 and Holz 1981) diatoms were characterized by the C16 acids $(16: 1 \omega 7,16: 2 \omega 4$, $16: 3 \omega 6,16: 3(1) 4,16: 401)$ and $20: 5 \omega 3$, while flagellates displayed mostly $\mathrm{C} 18$ acids $(18: 2 \omega 6,18: 3 \omega 3,18: 4 \omega 3$, $18: 5 \omega 3), 22: 6 \omega 3$ and surprisingly $16: 4 \omega 3$. The 2 periods of slow growth explained most of the remaining variance and proceeded through different biochemical pathways: bloom initiation or lag phase was associated with stearic acid and monoenes of the $\omega 9$ family $(18: 1 \omega 9,20: 1 \omega 9,22: 1 \omega 9)$ while bloom decay corresponded to a complex mixture of saturates $(14: 0,20: 0$.

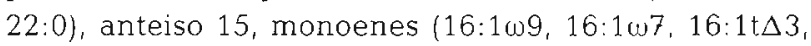


18:1 $\left.\omega_{7}\right)$ and 20:4w3. Most of the bacteriological biomass markers (anteiso 15, 18:1 $1{ }^{7}$ ) were in low percentages and associated with this latter period (Morris 1984, Morris et al. 1985). The cycle observed for the spring bloom confirmed that such changes were gradual and proceeded through what could be expected from a phytoplankton system facing: (1) exponential growth, (2) nutrient limitation, and (3) senescence and to a minor extent bacterial decay.

The sterol composition of surface marine particulate matter is often associated with the biological activity of the phytoplankton or the microzaoplankton (Gagosian 1975, Gagosian \& Nigrelli 1979). Most data obtained so far indicated that many sterols are widely distributed and few can be considered as characteristic of a particular algal class (see review by Morris \& Culkin 1977; Ballantine et al. 1979, Volkman et al. 1980, 1984, Nichols et al. 1984, Nichols et al. 1986). As indicated in a recent review by Volkman (1986) diatoms contain a wide variety of sterols although a single one often represents more than $80 \%$ of the total. In most species brassicasterol, cholesterol or fucosterol are dominant but with significant concentrations of stigmasterol or 24-methylenecholesterol. Similar unspecific pattern could be described for dinoflagellates with many species (but not all) containing an unusual sterol having $\Delta^{7}$ or $\Delta^{8}$ double bonds and 23,24-dimethyl substitution on the side chain (dinosterol) (Volkman 1986). Few chlorophytes contain mainly $\Delta^{5}$ unsaturated sterols and in this group most species displayed a dominance of 24 methylenecholesterol and stigmasterol with moderate amount of sitosterol. Prasinophyceae appears to contain essentially 24-methylenecholesterol and fucosterol but only Tetraselmis species have been analysed. Prymmesiophycea usually displayed a limited number of sterols with the predominance of cholesterol and brassicasterol. The spectrum of sterols observed in Bedford Basin is fairly similar to those observed in open ocean (Gagosian 1975) during experimental blooms (Morris 1984, Morris et al. 1985) or in laboratory cultures (Volkman 1986). On a percent basis, sterols with 27 and 28 carbons dominated with a minor contribution of the 26 and 29 carbon ones.

The non-specificity to taxonomic groups of the sterol distribution and the current lack of knowledge of the possible influence of the growth conditions prevented complete interpretation of the seasonal variation observed. Nevertheless, as suggested by Volkman (1986), comparisons of the inferences drawn from sterol data with information derived from other lipid classes as well as other particulate descriptors should help our general understanding. Because multivariate analyses are convenient ways to visualize in a multidimensional space the covariations among descriptors and the related seasonal succession, they represent a powerful tool to clarify such comparisons. Cholesterol and sitosterol were respectively associated with the early part of the bloom and the May transition period, also characterized by saturated and monoenoic fatty acids. Changes in 22-dehydrocholesterol, nor-24-cholesterol and brassicasterol were mostly associated with the summer production of small flagellates and the C18polyunsaturated fatty acids. 24-methylenecholesterol and desmosterol were related to the spring bloom of medium sized particles and the C16-polyunsaturated acids. Such relationships should not be viewed as taxonomic characteristics such as in pure culture but rather as the result of successions of dominant groups in the particle assemblages. Causal relationships cannot be established by means of statistical analyses but seasonal variation of any biochemical descriptor can safely be attributed to taxonomic changes in the population and physiological state. The present results suggest that although most sterols are present throughout the period considered, their seasonal distribution can be associated to specific periods (biological production) and size groups (taxonomic differences) in agreement with the conclusions derived from the fatty-acid data. The succession of spring diatoms and dinoflagellates and summer flagellates (prymnesiophytes, chlorophytes, cryptophyceae, dinophyceae) and diatoms could explain the shift from a dominance of 24 -methylenecholesterol, cholesterol and desmosterol to a pattern with cholesterol, brassicasterol and 22-dehydrocholesterol as increasingly important constituents. Whether changes in physiological state associated with periods of lower productivity could influence the sterol composition is unclear but should be investigated.

In a seasonal sequence such as the one observed in the surface water of Bedford Basin, the quantitative and qualitative definitions of the successions yielded somewhat different patterns. From the primary consumers' point of view, the abundance of particles was maximal during the spring bloom ( 9 March) and in June and minimal in April, but the quality of the potential food supply displayed wide variations as indicated by the $\mathrm{C}: \mathrm{N}$ or carbohydrate:protein ratios. The nutritional requirements of primary consumers such as copepods are little known: high levels of proteins are usually considered to be favorable to growth (Roman 1984, Paffenhöfer \& Van Sant 1985) and polyunsaturated fatty acids as well as cholesterol are probably required for proper development. Indeed, most data on marine invertebrates point to long-chain PUFA as essential fatty acids (Kanazawa et al. 1979a, b, Kayama et al. 1980, Enright et al. 1986) and cholesterol (Teshima 1972, Teshima \& Kanazawa 1986) as essential dietary factors. According to the results we have shown, Bedford Basin should face unfavorable protein conditions at the end of the bloom and in May and 
long-chain PUFA shortage in May. Growth limitation by sterol is unlikely as cholesterol is always a major component and crustaceans are able to interconvert various phytosterols into cholesterol (Teshima 1972). It is interesting that 1 yr later, Conover \& Mayzaud (1984) at the same station recorded positive growth rate efficiency for the copepod population throughout the spring bloom and negative values in May. To what extent such results were related to a nutritional limitation will need to be confirmed but the data point to an important role of food quality and likely PUFA in the copepod production.

Acknowledgements. The authors are grateful to Dr R. J. Conover from the Bedford Institute of Oceanography for making available logistic facilities. We also thank Dr M. Kovacs for his help in the analysis of sterols and their identification. Technical assistance by Mrs C. A. Eaton and J. Sipos was greatly appreciated. This work was supported in part by a NSERC grant \# A3667 and a FCAR team grant to P. M.

\section{LITERATURE CITED}

Ackman, R. G., Jangaard, P. M., Hoyle, R. J., Brockerhoff, H. (1964). Origin of marine fatty acids. I. Analyses of the fatty acids produced by the diatom Skeletonema costatum. J. Fish. Res. Bd Can. 21: 747-756

Ackman, R. G., Tocher, C. S., MacLachlan, J. (1968). Marine phytoplankters fatty acids. J. Fish. Res. Bd Can. 25: $1603-1620$

Antia, N. J., McAllister, C. D., Parsons, T. R., Stephens, K., Strickland, J. D. H. (1963). Further measurements of primary production using large volume plastic sphere. Limnol Oceanogr. 8: 166-183

Badour, S. S., Gergis, M. S. (1965). Cell division and fat accumulation in Nitzschia sp. grown in continued illuminated mass culture. Arch. Mikrobiol. 51: 94-102

Ballantine, J. A., Lavis, A., Morris, R. J. (1979). Sterols of the phytoplankton - effect of illumination and growth stage. Phytochemistry 18: 1459-1466

Bligh, E. G., Dyer, W. J. (1959). A rapid method of total lipid extraction and purification. Can. J. Biochem. Physiol. 37 : 911-917

Boussuge, C., Goutx, M., Tissier, M. J., Tusseau, D., Saliot, A. (1978). Sédimentation organique en mer arabe: biologie et transfert de lipides entre zone euphotique et interface océan - sédiment. In: CEPM-CNEXO (ed.) Géochimie organique des sédiments manns profonds. Orgon IV CNRS, Paris, p. 415-445

Chanut, J. P., Poulet, S. A. (1979). Distribution des spectres de taille des particules en suspension dans le fjord du Saguenay. Can. J. Earth Sci. 16: 240-249

Chanut, J, P., Poulet, S. A. (1982). Short term variability of the size spectra of suspended particles in a rapidly changing environment. Estuar. coast. Shelf Sci. 15: 197-513

Chanut, J. P., Poulet, S. A., Cossa, D., Marty, J. C. (1977). Factor analysis of suspended particulate matter in the estuary and gulf of St. Lawrence. Paper delivered at the First World conference on Mathematics at the service of man; 11-16 July, 1977 Technical session 215, Barcelona, Spain

Chuecas, L., Riley, J. P. (1969). Component fatty acids of the total lipids of some marine phytoplankton. J. mar. biol. Ass. U.K. $49.97-116$

Collier, A. (1967). Fatty acids of certain plankton organisms. In: Lauf, G. F. (ed.) Estuaries. Am. Ass. Adv. Sci., Washington, D.C., 83: 353-360

Conover, W. J. (1980). Practical nonparametric statistics, 2nd edn. Wiley, New York

Conover, S. A. M. (1975). Nitrogen utilization during spring blooms of marine phytoplankton in Bedford Basin, Nova Scotia, Canada. Mar. Biol. 32: 247-261

Conover, R. J., Mayzaud, P. (1984). Utilization of phytoplankton by zooplankton during the spring bloom in a Nova Scotia inlet. Can. J. Fish. Aquat. Sci. 41. 232-244

DeBaar, H. J. W., Farrington, J. W., Wakeham, S. G. (1983). Vertical flux of fatty acids in the North Atlantic ocean. J. mar. Res. 41. 19-41

DeMort, C. L., Lowry, R., Tinsley, I., Phinney, H. K. (1972). The biochemical analysis of some estuarine phytoplankton species. I. Fatty acid composition. J. Phycol. 8: 211-216

Enright, C. T., Newkirk, G. F., Craigie, J. S., Castell, J. D. (1986). Evaluation of phytoplankton as diets for juvenile Ostrea edulis L. J. exp. mar. Biol. Ecol. 96: 1-13

Eppley, R. W., Renger, E. H., Venrick, E. K., Mullin, M. M. (1973). A study of plankton dynamics and nutrient cycling in the central gyre of North Pacific Ocean. Limnol. Oceanogr. 18: 534-551

Escoufier, Y. (1973). Le traitement des variables vectorielles. Biometrics 29: 751-760

Fisher, N. S., Schwarzengach, R. P. (1978). Fatty acid dynamics in Thalassiosira pseudonana (Bacillariophycae) implications for physiological ecology. J. Phycol. 14 $143-150$

Fogg, G. E. (1956). Photosynthesis and formulation of fats in a diatom. A.nn. Bot. (N.S.) 20: 265-285

Gagosian, R. B. (1975). Sterols in the western North Atlantic Ocean. Geochim. Cosmochim. Acta 39: 1443-1454

Gagosian, R. B., Nigrelli, G. E. (1979). The transport and budget of sterols in the western North Atlantic Ocean Limnol. Oceanogr. 24: 838-849

Ganf, G. G., Stone, S. J. L., Oliver, R. L. (1986). Use of protein to carbohydrate ratios to analyse for nutrient deficiency in phytoplankton. Aust. J. mar. Freshwat. Res. 37: 183-197

Goutx, M. Saliot, A. (1980). Relationship between dissolved and particulate fatty acids and hydrocarbons, chlorophyll $a$ and zooplankton biomass in Villefranche Bay, Mediterranean Sea. Mar. Chem. 8: 299-318

Harrington, G. W., Beach, D. H., Dunham, J. E., Holtz, G. G. (1970). The polyunsaturated fatty acids in marine dinoflagellates. J. Protozool. 17: 213-219

Haug, A., Myklestad, S., Sakshaug, E. (1973). Studies on the phytoplankton ecology of the Trondheimfjord. I. The chemical composition of phytoplankton populations. J. exp. mar. Biol. Ecol. 11. 15-26

Holz, G. G. (1981). Non-isoprenoid lipids and lipid metabolism of marine flagellates. In: Biochemistry and physiology of protozoa, Vol. 4. Academic Press, New York, p. 301-332

Huang, W. Y., Meinschein, W G. (1976). Sterols as a source indicator of organic material in sediments. Geochum. Cosmochim. Acta 40: 323-330

Ibanez. F. (1971). Effet des transformations des données dans l'analyse factorielle en écologie planctonique. Cah. océanogr 23: 545-561

Irwin, B., Platt, I (1978). Phytoplankton productivity experiments and nutrient measurements in Bedford Basin, N.S from Sept. 1975 to Dec. 1976. Fish. and Mar. Serv., Ottawa, Fish. Mar Serv. Tech. Rep. 762, p. 1-128

Jeffrey, L. M. (1970). Lipids in marine waters. In: Wood, D. M 
(ed.) Proc. Symp. Organic Matter in natural sea water. Univ. Alaska Inst. Mar. Sci, Occ. publ. No. 1, p. 55-76

Jeffries, H. P. (1970). Seasonal composition of temperate plankton communities: fatty acids. Limnol. Oceanogr. 15: $419-426$

Jeffries, H. P. (1972). Fatty acid ecology of a tidal marsh. Limnol. Oceanogr. 17: 433-440

Jones, D. A., Kanazawa, A., Ono, K. (1979). Studies on the nutritional requirements of the larval stages of Penaeus japonicus using microencapsulated diets. Mar. Biol. 54 261-267

Kanazawa, A., Teshima, S., Ono, K. (1979a). Relationship between essential fatty acid requirements of aquatic animals and the capacity for bioconversion of linolenic acid into highly unsaturated fatty acids. Comp. Biochem. Physiol. 63B: 295-298

Kanazawa, A., Teshima, S. I., Tokiwa, S. (1977). Nutritional requirements of prawn. VIl-Effect of dietary lipids on growth. Bull. Jap. Soc. scient. Fish. 43: 849-856

Kanazawa, A., Teshima, S., Tokiwa, S., Kayama, M., Hirata, M. (1979b). Essential fatty acids in the diet of prawn. II. Effect of docosahexaenoic acid on growth. Bull. Jap. Soc. scient. Fish. 45: 1151-1153

Kates, M., Volcani, B. E. (1966). Lipid components of diatoms. Biochim. Biophys Acta 116: 264-278

Kattner, G., Gercken, G., Eberlein, K. (1983). Development of lipid during a spring bloom in the northern North Sea. I. Particulate fatty acids. Mar. Chem. 14: 149-162

Kayama, M., Hirata, M., Kanazawa, A., Tokiwa, S., Saito, M. (1980). Essential fatty acids in the diet of prawn. III. Lipid metabolism and fatty acid composition. Bull. Jap. Soc. scient. Fish. 46: 483-488

Kayama, M., Tsuchiya, Y., Mead, J. F. (1963). A model experiment of aquatic food chains with special significance in fatty acid conversion. Bull. Jap. Soc scient. Fish. 29: 452-458

Lebart, L., Morineau, A., Tabard, N. (1977). Technique de la description statistique. Dunod, Paris

Legendre, L., Legendre, P. (1984). Ecologie numérique. 2-La structure des données écologiques, 2e édn. Masson, Paris

Lewis, R. W (1969). The fatty acid composition of arctic marine phytoplankton and zooplankton with special reference to minor acids. Limnol. Oceanogr. 14: 35-40

Martin, B. J. (1980). Croissance et acides gras de la crevette Palaemon serratus nourrie avec des aliments composés contenant différentes proportions d'acide linoleique et linolenique. Aquaculture 19: 325-337

Mayzaud, P., Ackman, R. G. (1976). Some empirical observations on the choice of carrier gas in the chromatographie analysis of fatty acid methyl ester using wall coated open tubular columns. Chromatographia 9: 321-324

Mayzaud, P.. Taguchi, S. (1979). Size spectral and biochemical characteristics of the particulate matter in the Bedford Basin. J. Fish. Res. Bd Can. 36: 211-218

Mayzaud, P., Taguchi, S., Laval, P. (1984). Seasonal patterns of seston characteristics in Bedford basin, N.S., relative to zooplankton feeding: a multivariate approach. Limnol Oceanogr. 29: 745-762

Miller, J. D. A. (1962). Fats and steroids. In: Lewin, R. A. (ed.) Physiology and biochemistry of algae. Academic Press New York, p. 357-370

Moreno, V. J., Morens, J. E. A., Brenner, R. R. (1979). Biosynthesis of unsaturated fatty acids in the diatom Phaeodactylum tricomutum. Lipids 14: 15-19

Morris, R. J. (1984). Studies of a spring phytoplankton bloom in an enclosed experimental ecosystem. II. Changes in the component fatty acids and sterols. J. exp. mar Biol. Ecol. 75: $59-70$
Morris, R. J., Culkin, F. (1976). Marine lipids: analytical techniques and fatty acid esters analysis. Oceanogr. mar biol. A. Rev. 14: 391-433

Morris, R. J. Culkin, F. (1977). Marine lipids: sterols. Oceanogr mar. biol. A. Rev. 15: 73-102

Morris, R. J., McCartney, M. J., Jocut, I. R., Robinson, G. A. (1985). Further studies of a spring phytoplankton bloom in an enclosed experimental ecosystem. J. exp. mar Biol Ecol. 86: 151-170

Nichols, B. W. (1965). Light induced changes in the lipids of Chlorella vulgaris. Biochim. Biophys. Acta 106: 274-279

Nichols, P. D., Jones, G. J., De Leeuw, J. W., Johns, R. B (1984). The fatty acid and sterol composition of two marine dinoflagellates. Phytochemistry 5: 1043-1047

Nichols, P. D., Palmisano, A. C., Smith, G. A., White, D. C. (1986). The lipids of the antarctic sea ice diatom Nitzschia cylindricus. Phytochemistry 7: 1649-1653

Orcutt, D. M., Patterson, G. W. (1975). Sterol, fatty acid and elemental composition of diatoms grown in chemically defined medium. Comp. Biochem. Physiol. 50B: 579-583

Paffenhöfer, G.-A., Van Sant, K. B. (1985). The feeding response of a marine planktonic copepod to quantity and quality of particles. Mar. Ecol. Prog. Ser. 27: 55-65

Paoletti, C., Pelosi, E., Pushparaj, B. (1974). The influence of culture conditions on the fatty acids composition of Scenedesmus sp. III. The influence of temperature. Riv. It Sost. Grasse, 51-62-65 (Fisheries and Marine Service, Ottawa, Translation No. 3198)

Parrish, C. C. (1987). Time series of particulate and dissolved lipid classes during spring phytoplankton blooms in Bedford Basin, a marine inlet. Mar. Ecol. Prog. Ser. 35: 129-139

Perry, M. J. (1976). Phosphate utilization by an oceanic diatom in phosphorus-limited chemostat culture and in the oligotrophic waters of the central North Pacific. Limnol. Oceanogr. 21: 88-107

Pöl, P., Wagner, M. (1972). Control of fatty acid and lipid biosynthesis in Euglena gracilis by ammonia, light and DCMU. Z. Naturforsch. 27b: 53-61

Pöhl, P., Zurheide, F. (1979). Fatty acids and lipids of marine algae and the control of their biosynthesis by environmental factors. In: Hoppe, H. A., Levring, T., Tanaka, Y (ed.) Marine algae in pharmaceutical science. Walter de Gruyter, Berlin, p. 473-523

Poulet, S. A. (1974). Seasonal grazing of Pseudocalanus minutus on particles. Mar. Biol. 25: 109-123

Poulet, S. A., Cossa, D., Marty, J.-C. (1986). Combined analyses of the size spectra and biochemical composition of particles in the St. Lawrence estuary. Mar. Ecol. Prog. Ser. 30: $205-214$

Rao, C. R. (1964). The use and interpretation of principal component analysis in applied research. Sankhya A26: 329-358

Richman, S., Dodson, S. I. (1983). The effect of food quality on feeding and respiration by Daphnia and Diaptomus. Limnol. Oceanogr. 28: 948-956

Riley, G. A. (1970). Particulate organic matter in the sea water Adv. mar. Biol. 8: 1-118

Roman, M. R. (1984). Utilization of detritus by the copepod Acartia tonsa. Limnol. Oceanogr. 29: 949-959

Sakshaug, E., Myklestad, S. (1973). Studies on the phytoplankton ecology of the Trondheimfjord. III. Dynamics of phytoplankton blooms in relation to environmental factors, bioassay experiments and parameters for the physiological state of the populations. J. exp. Mar. Biol. Ecol. 11: 157-188

Sakshaug, E., Myklestad, S., Andresen, K., Hegseth, E. N. Jorgensen, L. (1981). Phytoplankton off the More coast in 
1975-1979: distribution, species composition, chemical composition and conditions for growth. In: Proc. Symp. Norw. Coastal Current, Geib, Sept. 1980. Univ. Bergen, p. $681-711$

Sakshaug, E., Andresen, K., Myklestad, S., Olsen, Y (1983). Nutrient status of phytoplankton communities in Norwegian waters (marine, brackish and fresh) as revealed by their chemical composition. J. Plankton Res. 5: 175-196

Saliot, A., Goutx, M., Fevrier, A., Tusseau, D., Andrie, C (1982). Organic sedimentation in the water column in the Arabian Sea: relationship between the lipid composition of small and large, surface and deep particles. Mar. Chem. 11: $257-278$

Sandifer, P. A., Joseph, J. D. (1976). Growth response and fatty acid composition of juvenile prawns (Macrobrachium rosenbergii) fed a prepared ration augmented with shrimp head oil. Aquaculture 8: 129-138

Sargent, J. R. (1976). The structure, metabolism and function of lipids in marine organisms. In: Malins, D. C., Sargent, J. R. (ed.) Biochemical and biophysical perspectives in marine biology, Vol. 3. Academic Press, London, p. 149-212

Schultz, D. (1974). Source, formation and composition of suspended lipoidal material in Narragansett Bay, Rhode Island. Ph.D. thesis, University Rhode Island

Sheldon, R. W. (1973). Direct measurement of particle concentrations in natural waters with a model $T$ Coulter counter. Fish. Res. Bd Can. Tech. Rep. 379, p. 1-25

Sheldon, R. W., Prakash, A., Sutcliffe, W. H. J. (1972). The size distribution of particles in ocean. Limnol. Oceanogr. 17: $327-340$

This article was presented by Dr R. J. Conover, Dartmouth, Nova Scotia, Canada
Shitrin, N. S., Chisholm, S. W. (1981). Phytoplankton lipids. Interspecific differences and effects of nitrate, silicate and light-dark cycles. J. Phycol. 17: 374-384

Taguchi, S., Platt, T (1978a). Phytoplankton biomass in Bedford Basin: volume, surface area, carbon content and size distribution. Fish. Mar. Serv. Data Rep. 55, p. 1-404

Taguchi, S., Platt, T. (1978b). Size distribution and chemical composition of particulate matter in Bedford Basin in 1973. 1974. Fish. Mar. Serv. Data Rep. 56, p. 1-371

Teshima, S. I. (1972). Studies on the sterol metabolism in marine crustacean. Mem. Fac. Fish. Kagoshima Univ. 21. $69-117$

Teshima, S. I., Kanazawa, A. (1986). Nutritive sterols for the juvenile prawn. Bull. Jap. Soc. scient. Fish. 52: 1417-1422

Teshima, S. I., Kanazawa, A., Sasada, M. (1983). Nutritional value of dietary cholesterol and other sterols to larval prawn, Penaeus japonicus. Aquaculture 31: 159-167

Volkman, J. K. (1986). A review of sterol markers for marine and terrigenous organic matter. Org. Geochem. 9: 83-99

Volkman, J. K., Eglinton, G., Comer, E. D. S. (1980). Sterols and fatty acids of the marine diatom Biddulphia sinensis. Phytochemistry 19: 1809-1813

Volkman, J. K., Gagosian, R. B., Wakeham, S. G. (1984). Free and esterified sterols of the marine dinoflagellate Gonyaulax polygramma. Lipids 19: 457-465

Williams, P. M. (1965). Fatty acids derived from lipids of marine origin. J. Fish. Res. Bd Can. 22: 1107-1122

Wood, B. J. B. (1974). Fatty acids and saponifiable lipids. In: Stewart, D. W. (ed.) Algae physiology and biochemistry. Blackwell, Oxford, p. 236-265

Manuscript first received: October 25, 1988

Revised version accepted: May 9, 1989 